九州大学学術情報リポジトリ

Kyushu University Institutional Repository

\title{
Physicochemical Properties Related to Palatability of Chinese japonica-type Rice
}

Cui, Jing

China-Japan Joint Research Center on Palatability and Quality of Rice, Tianjin Agricultural University

Zhang, Xin

China-Japan Joint Research Center on Palatability and Quality of Rice, Tianjin Agricultural University

Cui, Zhongqiu

United Graduate School of Agricultural Sciences, Ehime University

Huang, Xiaoshan

Seed Management Bureau of Shiyan City

他

https://doi.org/10.5109/1564083

出版情報: 九州大学大学院農学研究院紀要. 61 (1)，pp.59-63，2016-02-29. Faculty of Agriculture， Kyushu University

バージョン：

権利関係： 


\title{
Physicochemical Properties Related to Palatability of Chinese japonica-type Rice
}

\author{
Jing CUI ${ }^{1}$, Xin ZHANG ${ }^{1}$, Zhongqiu CUI $^{2}$, Xiaoshan HUANG ${ }^{3}$, \\ Akihito KUSUTANI ${ }^{1}$, Shoichi ITO ${ }^{4}$ and Yuji MATSUE ${ }^{4 *}$
${ }^{1}$ China-Japan Joint Research Center on Palatability and Quality of Rice, Tianjin Agricultural University, Tianjin 300384, China
${ }^{2}$ United Graduate School of Agricultural Sciences, Ehime University, Matsuyama 790-8566, Japan ${ }^{3}$ Seed Management Bureau of Shiyan City, Hubei Province, China
${ }^{4}$ Department of Agricultural and Resource Economics, Faculty of Agriculture, Kyushu University, Fukuoka 812-8581, Japan (Received November 11, 2015 and accepted November 19, 2015)

\begin{abstract}
To obtain basic information for palatability breeding of japonica-type paddy rice in China, we collected 260 varieties from northern area of China, and examined their physicochemical properties (amylose and protein contents of polished rice, breakdown value of polished rice flour and hardness/adhesion ratio of cooked rice). In all physicochemical properties, genetic variation was larger in Chinese rice varieties than in Japanese rice varieties. In Chinese rice varieties, amylose content showed a negative correlation with breakdown value and positive correlation with hardness/adhesion ratio as in Japanese rice varieties. However, the protein content showed a negative correlation with amylose content and positive correlation with breakdown value, in contrast to Japanese rice varieties. Among the 260 varieties examined, Zaoyou3, Liaohui253-2, Jing350 and E35-6 had superior physicochemical properties as in palatable Japanese varieties. These varieties may be useful as parents to breed palatable varieties in China.
\end{abstract}

Key words: Chinese japonica-type rice varieties, Genetic correlation, Genetic variation, Palatability, Physicochemical properties.

\section{INTRODUCTION}

Recently, accompanied with the diversification of diet, the demand of the consumer for highly-palatable rice is increasing in China. In addition, high quality palatable rice is bought and sold at a high price by producers and distributers, and breeding of palatable rice is awaited. In China, however, a unified evaluation method for palatability of rice has not been established, and selection based on the palatability is not conducted (Cui et al., 2011).

Palatability is evaluated either by a sensory test or physicochemical properties determined using machinery (Matsue, 2012). The sensory test is more reliable and preferable, but a large panel and long time for preparation are necessary. Therefore, it is difficult to use the sensory test in the early step of breeding in which a lot of materials are used. In Japan, therefore, breeding of palatable rice is usually performed by using physicochemical properties which can be measured rapidly by using machinery.

In this respect, we have to analyze the correlation between sensory palatability and physicochemical characteristics. Studies by Inatsu (1988) and Matsue (1993) showed that amylose content and protein content of chemical components are correlated with the palatability of rice, and that the lower the amylose content and protein content, the higher the palatability. Concerning the

${ }^{1}$ China-Japan Joint Research Center on Palatability and Quality of Rice, Tianjin Agricultural University

${ }^{2}$ United Graduate School of Agricultural Sciences, Ehime University

Seed Management Bureau of Shiyan City, Hubei Province

${ }^{4}$ Department of Agricultural and Resource Economics, Faculty of Agriculture, Kyushu University

* Corresponding author (E-mail:matsue@farm. Kyushu-u. ac.jp) physical properties, the maximum viscosity and breakdown value related to amylogram properties, and hardness/adhesion ratio related to texture properties are important. The larger the maximum viscosity and breakdown value, and the lower the hardness/adhesion ratio, the higher the palatability. These physicochemical properties are considered to be the effective indicators for breeding palatable varieties. To select the varieties based on physicochemical properties, it is necessary to examine the physicochemical properties of many varieties and to grasp the genetic variation and genetic correlation between the properties. Accumulation of the information related to physicochemical properties of many varieties may be important for selecting parents for crossing. However, such information on Chinese rice varieties is scarce (Cui et al., 1999a, 2000).

In this study, therefore, we examined physicochemical properties related to palatability in many varieties and lines of japonica-type paddy rice bred at various sites in China, and analyzed the varietal difference and interrelation among the properties. Based on the results we discuss the course and direction of breeding of palatable rice varieties in China.

\section{MATERIALS AND METHODES}

\section{Used varieties and cultivation method}

In 2008, 260 varieties and lines (simply called varieties, hereafter) bred in the northern region of China were used. They were 24 varieties from Heilongjiang Province, 115 varieties from Liaoning Province, 116 varieties from Tianjin Municipality, and 5 varieties from Jiangsu Province.

On June 1 , seedlings grown in the nursery for 46 days were transplanted at a density of 22.2 hills $/ \mathrm{m}^{2}(30 \mathrm{~cm}$ 
row spacing and $15 \mathrm{~cm}$ hill spacing), one plant per hill. For basal dressing $14.8 \mathrm{~kg} / 10 \mathrm{a}$ nitrogen and $8.7 \mathrm{~kg} / 10 \mathrm{a}$ phosphate, and for top dressing $11.7 \mathrm{~kg} / 10 \mathrm{a}$ nitrogen were applied at the panicle formation stage. Experiments were repeated three times each with 54 hills in a row $(8 \mathrm{~m})$.

\section{Methods of measuring physicochemical properties}

In all varieties, 91-92\% polished rice was used, and the physicochemical properties were examined at the China-Japan Joint Research Center on Palatability and Quality of Rice in Tianjin Agricultural University. Amylose and protein contents of polished rice were measured by using an Auto Analyzer AA-3 (BRAN LUEBBE Co.). The protein content was shown on a dry matter basis. Breakdown of polished rice flour was measured with a Rapid Visco Analyzer RVA-4 (NEWPORT SIENTIFIC Co.). Hardness and adhesion of cooked rice were measured with a Rice Hardness-Viscosity Meter RHS-1A (SATAKE Co.).

\section{RESULTS}

\section{Varietal difference in physicochemical properties}

Table 1 shows the variation of each physicochemical property. Amylose content was 15.1-20.1\%, average was $18.1 \%$, and variation coefficient was $5.3 \%$. Protein content was $6.5-13.4 \%$, average was $9.8 \%$, and variation coefficient was $14.7 \%$ which was larger than that of amylose content. Breakdown value was 48-140 RVU, average was 93 RVU, and variation coefficient was $17.6 \%$. Hardness/ adhesion ratio was 7.2-57.9, average was 23.8 , and variation coefficient was $37.5 \%$ which was the largest among the physicochemical properties examined.

Fig. 1 shows the frequency distribution of physicochemical properties in 260 varieties examined. The amylose content was less than $16 \%$ in 6 varieties, $16-17 \%$ in 30 varieties, $17-18 \%$ in 77 varieties, $18-19 \%$ in 96 varieties, and $19-20 \%$ in 49 varieties. It was over $20 \%$ only in 2 varieties. Protein content was less than $7 \%$ in 3 varieties, $7-8 \%$ in 24 varieties, $8-9 \%$ in 54 varieties, $9-10 \%$ in 71 varieties, and over $10 \%$ in remaining 108 varieties. Breakdown value was less than 80 RVU in 56 varieties, 80-89 RVU in 63 varieties, and 90-99 RVU in 60 varieties. It was over $100 \mathrm{RVU}$ in 81 varieties and over $130 \mathrm{RVU}$ in 6 varieties. Hardness/adhesion ratio was less than 10 in 9 varieties, 10-20 in 76 varieties, $20-30$ in 120 varieties and higher than 30 in 55 varieties.

\section{Relationship among different physicochemical properties}

Fig. 2 shows the relationship between amylose content and protein contents. Fig. 3 shows the relationship
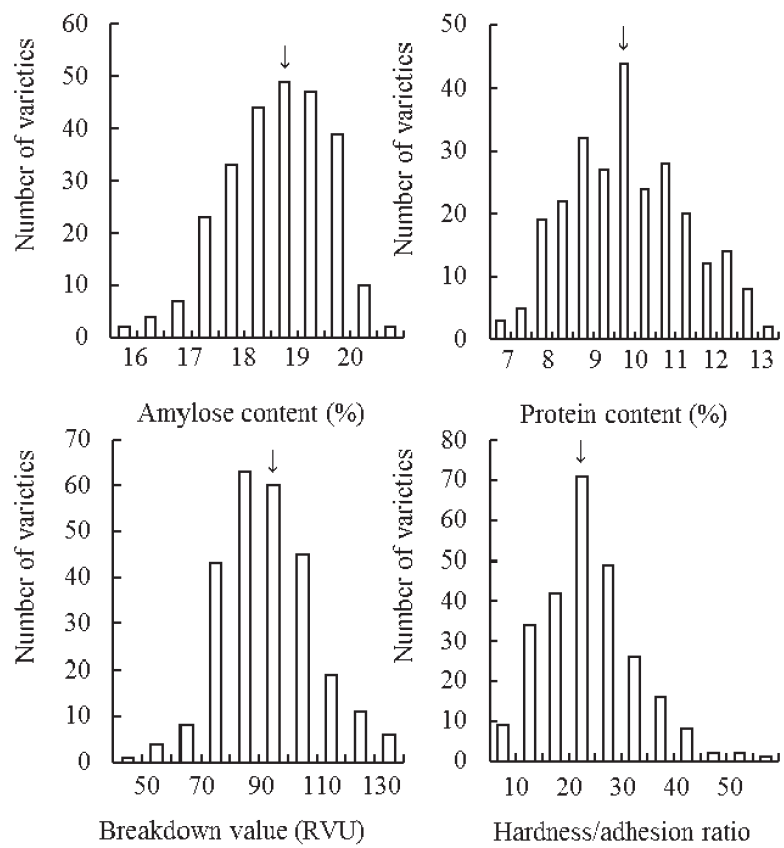

Fig. 1. Frequency distribution of physicochemical properties in 260 varieties examined. $\rightarrow$ : Mean value.

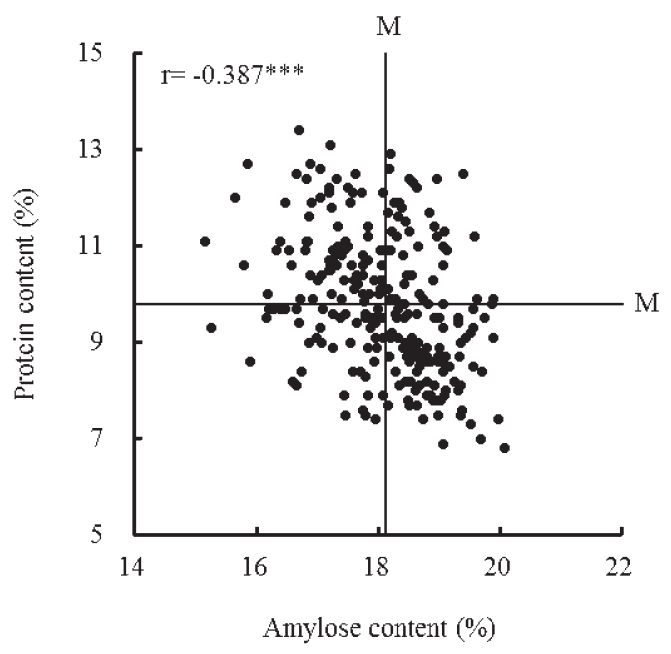

Fig. 2. Correlation between amylose content and protein content.

***: Significant at $0.1 \%$ level.

M: Mean value.

Table 1. Variation of physicochemical properties in 260 examined varieties

\begin{tabular}{|c|c|c|c|c|c|}
\hline & $\begin{array}{l}\text { Minimun } \\
\text { value }\end{array}$ & $\begin{array}{l}\text { Maximun } \\
\text { value }\end{array}$ & $\begin{array}{l}\text { Mean } \\
\text { value }\end{array}$ & $\begin{array}{l}\text { Standard } \\
\text { deviation }\end{array}$ & $\begin{array}{l}\text { Coefficient of } \\
\text { variation }(\%)\end{array}$ \\
\hline Amylose content (\%) & 15.1 & 20.1 & 18.1 & 0.95 & 5.3 \\
\hline Protein content (\%) & 6.5 & 13.4 & 9.8 & 1.44 & 14.7 \\
\hline Breakdown value (RVU) & 48 & 140 & 93 & 16.3 & 17.6 \\
\hline Hardness/adhesion ratio & 7.2 & 57.9 & 23.8 & 8.9 & 37.5 \\
\hline
\end{tabular}




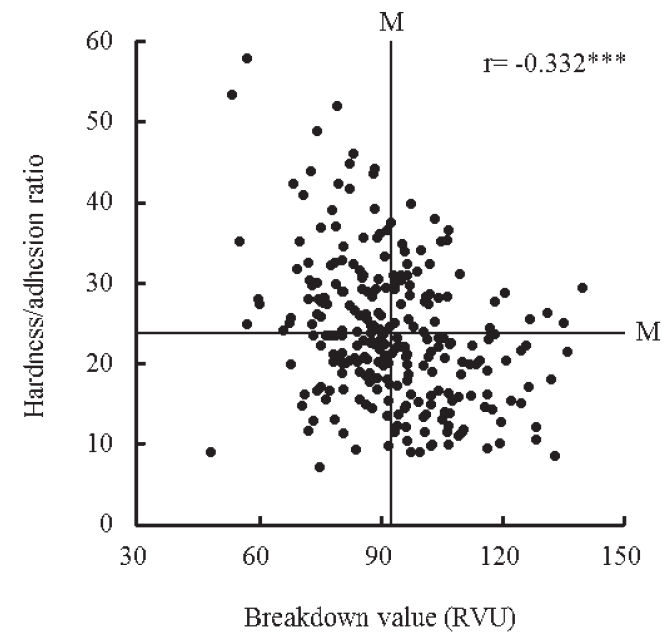

Fig. 3. Correlation between breakdown values and hardness/adhesion ratio.

***: Significant at $0.1 \%$ level.

M: Mean value.

between breakdown value and hardness/adhesion ratio. A significant negative correlation was observed between amylose content and protein content. Breakdown value had a significant negative correlation with hardness/adhesion ratio.

Table 2 shows the correlation coefficient among physicochemical properties. Amylose content had a significant negative correlation with breakdown value, and significant positive correlation with hardness/adhesion ratio. On the other hand, protein content did not show a significant correlation with hardness/adhesion ratio, but had a significant positive correlation with breakdown value.

\section{Selection of varieties with superior physicochemi- cal properties}

The lower the amylose and protein contents, the greater the breakdown value and the lower the hardness/ adhesion ratio, the higher the palatability. According to the study by Matsue (1993), the standard for palatable rice in Japanese rice varieties is amylose content under $20 \%$, protein content under $8.5 \%$ and breakdown value 100 RVU or more. The standard of hardness/adhesion ratio was not reported, but palatability decreased rapidly when the ratio exceeded 20 (Matsue, 2012). Therefore in this study, we used the hardness/adhesion ratio of 20 as the standard. We selected the varieties that fulfill these standards of palatability. The number of varieties with an amylose content under 20\% was 258 (99.2\%), those with a protein content under $8.5 \%$ was 49 (18.8\%), those with breakdown value of $100 \mathrm{RVU}$ or more was 81 $(31.2 \%)$, and hardness/adhesion ratio under 20 was 85 (32.7\%). Thus, less than $20 \%$ of the varieties met the standard in protein content, but more than 30\% surpassed the Japanese standard for palatable rice in the other physicochemical properties. However, the number of cultivars with more than one physicochemical property that fulfilled the palatability standard was small. There were $9(3.5 \%)$ varieties with both amylose and protein contents meeting the standard level. Varieties fulfilled breakdown value and hardness/adhesion ratio were 41(15.8\%). Only 4 (1.5\%) of the varieties met the standard levels for all four properties.

Table 3 shows the physicochemical properties of these four varieties, one from Heilongjiang Province, one from Liaoning Province, and two from Tianjin Municipality. In Zaoyou3 amylose and protein contents were lowest, breakdown value was highest of four varieties, but hardness/adhesion ratio tended to be larger than in other varieties. In Liaohui253-2, hardness/adhesion ratio was lowest, but breakdown value was at the lowest limit of standard, and protein content was higher than in other varieties. In Jing350, protein content was low, but hardness/adhesion ratio was higher than in other varieties. In E35-6, protein content and hardness/adhesion ratio were near average of four varieties, but amylose content was around 1\% higher than in other three varieties, and breakdown value was the lowest limit of the standard.

Table 2. Correlation coefficient between different physicochemical properties

\begin{tabular}{|c|c|c|c|}
\hline & Protein content & Breakdown value & Hardness/adhesion ratio \\
\hline Amylose content & $-0.387 * * *$ & $-0.444^{* * *}$ & $0.307 * * *$ \\
\hline Protein content & & $0.228 * * *$ & -0.087 \\
\hline Breakdown value & & & $-0.332 * * *$ \\
\hline
\end{tabular}

***: Significant at $0.1 \%$ level.

Table 3. Physicochemical properties of four selected varieties

\begin{tabular}{lccccc}
\hline $\begin{array}{c}\text { Cropping } \\
\text { location }\end{array}$ & Variety & $\begin{array}{c}\text { Amylose } \\
\text { content (\%) }\end{array}$ & $\begin{array}{c}\text { Protein } \\
\text { content (\%) }\end{array}$ & $\begin{array}{c}\text { Breakdown } \\
\text { value (RVU) }\end{array}$ & $\begin{array}{c}\text { Hardness/ } \\
\text { adhesion ratio }\end{array}$ \\
\hline Heilongjiang Province & Zaoyou3 & 17.5 & 7.5 & 109 & 15.9 \\
Liaoning Province & Liaohui253-2 & 17.8 & 8.3 & 7.5 & 100 \\
Tianjin Municipality & Jing350 & 17.8 & 7.7 & 104 & 100 \\
Tianjin Municipality & E35-6 & 18.6 & & 13.5 \\
\hline
\end{tabular}




\section{DISCUSSION}

In this study, amylose content under $20 \%$, protein content under $8.5 \%$, breakdown value over 100RVU and hardness/adhesion ratio under 20 were regarded as the standard of palatable rice (Matsue, 1993). As a result, 258 of the 260 varieties fulfilled the standard of amylase content (Table 1, Fig. 1). Protein content fulfilled the standard in 49 varieties, breakdown in 81 varieties and hardness/adhesion ratio in 85 varieties. On the other hand, in 180 of 260 varieties, protein content was higher than $10 \%$ and in 24 varieties it was higher than $12 \%$. Breakdown value was less than 80 RVU in 56 varieties, and less than 70 RVU in 13 varieties. The hardness/adhesion ratio was higher than 30 in 58 varieties and higher than 40 in 13 varieties. Thus, in 260 varieties examined, physicochemical properties varied from extremely high to extremely low levels. In breeding for palatability in Japan, lines are usually selected by investigating some physicochemical properties from an early generation after crossing. Therefore, lines with inferior physiochemical properties are discarded in the early generation, so under general cultivation conditions there exist no varieties with a $>12 \%$ protein content, $<70$ RVU breakdown value, and $>40$ hardness/adhesion ratio. In China, as well, selection by physicochemical properties from an early generation may be useful for efficiently breeding highly palatable varieties.

In this study, breakdown value showed significant negative correlations with the hardness/adhesion ratio (Fig. 3) and amylose content(Table 2). Amylose content also had a significant positive correlation with the hardness/adhesion ratio (Table 2). In other words, varieties with low amylose content had superior amylogram property and superior texture property (Inatsu, 1988; Matsue, 1993, 2012; Cui et al., 1999a, 2000). However, protein content was correlated negatively with amylose content (Fig. 2) and positively with breakdown value (Table 2). That is, varieties with low protein content had high amylose content and inferior amylogram property, which are not preferable to palatability. In 260 varieties used in this study, protein content of Chinese rice varieties was generally higher than that of Japanese rice varieties. Thus, the most considerable properties of Chinese rice is the protein content (Cui et al., 2001). Therefore, it is important to improve the correlation of protein content with other physicochemical properties, in particular, to diminish negative correlation between protein content and amylose content, in order to breed highly palatable varieties in China. Since the correlation coefficients between protein content and other physicochemical properties were less than \pm 0.4 (Table 2), the genetic correlation may not be strong. Therefore, it may be possible to concentrate superior genes for palatability by crossing varieties that have low protein content with those which are superior in other physicochemical properties.

As mentioned previously, many of the Chinese rice varieties used in this study have superior physicochemical properties as in Japanese highly palatable varieties.
This is true for each physicochemical property, but not for their combination. There were many varieties superior in one physicochemical property but inferior in other physicochemical properties (Cui et al., 2000). Among them, Zaoyou3, Liaohui 253-2, Jing 350 and E35-6 fulfilled the Japanese standard of palatable rice in all of the four physicochemical properties, amylose content, protein content, breakdown value and hardness/ adhesion ratio (Table 3). These four varieties are expected to be useful as the parents of crossing for breeding palatable rice in China. However, these standards of palatable rice were established about 20 years ago (Matsue, 1993). At present the standard of palatable rice in Japan is higher, that seems amylose content is $<18.0 \%$, protein content $<7.5 \%$, breakdown value $>150 \mathrm{RVU}$ and hardness/adhesion ratio $<15$ (Matsue, 2012). In China, as well, it is necessary to establish a breeding method using physicochemical properties as selection indicators, and breed highly palatable varieties.

Chinese rice varieties used in this study had a higher protein content than the Japanese rice varieties, but this may not be due simply to the genetic difference. The protein content of rice is influence by the amount of fertilizer applied, in particular nitrogen fertilizer (Inatsu, 1988). In China, several times larger amount of fertilizer than in Japan are used (Cui et al., 1998b). In this study also $26.5 \mathrm{~kg} / 10 \mathrm{a}$ of nitrogen that is $3-4$ times larger than standard fertilizer in Japan were applied. Therefore, the larger amount of nitrogen fertilizer applied may be the reason why Chine rice has a high protein content. Studies on the relationship between fertilizing method and physicochemical properties, particularly protein content may be an important subject in future studies on rice palatability in China.

\section{REFERENCES}

Cui, J., A. Yamamura, A. Kusutani, M. Toyota, M. Morokuma, K. Asanuma, M. Ichii, H. Tanno, R. Zhang and D. Hong 1999a. Studies on Palatability of Chinese and Japanese Rice CultivarsComparison under the same cultivation condition-. Shikoku J. Crop Sci. 36: $1-13^{*}$

Cui, J., A. Yamamura, A. Kusutani, M. Toyota, M. Morokuma, K. Asanuma, H. Tanno, J. Zhao, Y. Li and X. Chen 1999b. Studies on Palatability of Chinese and Japanese Rice CultivarsDifference between producing districts, Kagawa in Japan and Tianjin in China-. Shikoku J. Crop Sci. 36: 14-27*

Cui, J., J. Zhao, A. Kusutani, M. Morokuma, M. Toyota, K. Asanuma and H. Tanno 2000. Studies on Palatability of Rice Grown in Tianjin District, China-Varietal difference-. Jpn. J. Crop Sci. 69: 314-319**

Cui, J., A. Kusutani, J. Zhao, J. Liu, X. Chen, M. Morokuma, M. Toyota and K. Asanuma 2001. Studies on Palatability of Chinese and Japanese Rice Cultivars-Characteristics with reference to grain-protein content-. Shikoku J. Crop Sci. 38 $1-15^{*}$

Cui, J., Y. Matsue, A. Kusutani, D. D. Liang, X. Zhang and S. Morita 2011. Sensory Test on Japonica-type Chinese Rice Cultivars by Japanese and Chinese Panels. Jpn. J. Crop Sci. 80: 84-89**

Inatsu, O. 1988. Studies on Improving the Eating Quality of Hokkaido Rice. Report of Hokkaido Prefectural Agricultural Experiment Stations 66: $1-89 *$

Matsue, Y. 1993. The Effects of Environmental Conditions on 
Palatability and Physicochemical Properties of Rice and the Evaluation of Good Eating Quality Rice Varieties. R ep. of Special Bull. of Fukuoka Agric. Res. Cent. 6: 1-73**

Matsue, Y. 2012. Palatability Science of Rice. Yokendo, Tokyo,
Japan: 1-141*

* :In Japanese.

**:In Japanese with English abstract 